\title{
Perbandingan Pemberian Variasi Konsentrasi Pupuk dari Limbah Cair Tahu Terhadap Pertumbuhan Tanaman Cabai Rawit (Capsicum frutescens $\mathrm{L}$. )
}

\author{
Wakhida Amalia1, Nur Hayati², Kusrinah ${ }^{3}$ \\ Prodi Pendidikan Biologi, Fakultas Sains dan Teknologi, UIN Walisongo Semarang \\ Email: 1amalia.wakhida10@gmail.com, 2nur_hayati@walisongo.ac.id, ${ }^{3}$ kusrinah@walisongo.ac.id
}

\begin{abstract}
Abstrak
Tanaman Cabai Rawit (Capsicum frutescens L.) merupakan salah satu komoditas di Indonesia. Sektor pertanian di Indonesia masih mengandalkan pupuk anorganik untuk meningkatkan produktivitas tanaman Cabai Rawit (Capsicum frutescens L.). Pemberian pupuk anorganik berlebih menyebabkan berkurangnya kesuburan tanah. Pupuk organik dari limbah cair tahu dapat dijadikan sebagai alternatif untuk mengurangi penggunaan pupuk anorganik. Limbah cair tahu difermentasi selama 10 hari dengan bahan tambahan EM4 dan air kelapa. Penelitian ini bertujuan untuk mengetahui perbandingan pemberian variasi konsentrasi pupuk dari limbah cair tahu terhadap pertumbuhan tanaman Cabai Rawit (Capsicum frutescens L.). Penelitian ini menggunakan pendekatan kuantitatif dengan metode eksperimen. Rancangan percobaan yang digunakan dalam penelitian ini yaitu Rancangan Acak Lengkap (RAL) dengan 4 kali ulangan. Perlakuan dalam penelitian ini berjumlah 5 yaitu pupuk 0\% (kontrol), 5\%, 10\%, 15\%, dan 20\%. Pengamatan dilakukan terhadap tiga parameter pertumbuhan yaitu diameter batang, tinggi tanaman, dan jumlah helai daun. Analisis data menggunakan One-way ANOVA dan Uji lanjutan Beda Nyata Terkecil (BNT) pada taraf signifikansi 5\% $(\alpha=0,05)$. Hasil uji One-way ANOVA menunjukkan $\mathrm{F}_{\text {hitung }}$ diameter batang, tinggi tanaman, dan jumlah helai daun lebih besar dibandingkan $\mathrm{F}_{\text {tabel }}$ pada $\alpha=5 \%$. Uji BNT menunjukkan pada perlakuan pupuk konsentrasi 5\%, 10\%, 15\% dan 20\% menunjukkan perbedaan dibanding perlakuan kontrol.
\end{abstract}

Kata Kunci : pupuk, limbah cair tahu, pertumbuhan, cabai rawit

\begin{abstract}
Red pepper (Capsicum frutescens L.) is one commodity in Indonesia. The agricultural sector in Indonesia still rely on inorganic fertilizers to increase crop productivity Red Pepper (Capsicum frutescens L.). Inorganic fertilizer application of excess leads to reduced soil fertility. Organic fertilizer from tofu liquid waste can be used as an alternative to reduce the use of inorganic fertilizers. Tofu liquid waste fermented for 10 days with additional material EM4 and coconut water. This study aimed to compare the administration of varying concentrations of fertilizer from liquid waste out of the plant growth Red Pepper (Capsicum frutescens L.). This study uses a quantitative approach with the experimental method. The experimental design used in this research is completely randomized design (CRD) with four replications. The treatment in this study amounted to 5 ie fertilizer $0 \%$ (control), 5\%, 10\%, 15\% and $20 \%$. Observations were made on three parameters, namely the growth of stem diameter, plant height, and number of leaves. Analysis of data using One-way ANOVA and advanced Least Significant Difference Test (LSD) at $5 \%$ significance level $(\alpha=0.05)$. Results One-way ANOVA test showed $\mathrm{F}_{\text {value of stem }}$ diameter, plant height, and number of leaves is greater than the $F_{\text {table }}$ at $\alpha=5 \%$. LSD showed the fertilizer treatment concentration of 5\%,10\%,15\% and 20\% showed differences compared to control treatment.
\end{abstract}

Keywords : fertilizer, tofu liquid waste, growth, red pepper 


\section{Pendahuluan}

Cabai rawit merupakan salah satu komoditas di Indonesia. Cabai rawit banyak digunakan oleh masyarakat untuk campuran berbagai masakan. Pemanfaatan cabai rawit terus meningkat setiap tahun sejalan dengan meningkatnya jumlah penduduk dan berkembangnya industri yang membutuhkan bahan baku cabai rawit. Usaha menaikkan produktivitas tanaman cabai rawit dilakukan dengan cara pemberian pupuk. Sektor pertanian saat ini masih banyak menggunakan pupuk anorganik buatan (pupuk kimia).

Harga pupuk anorganik masih tinggi dan sulit dijangkau petani. Tingginya harga pupuk tersebut menyebabkan biaya pengeluaran juga menjadi tinggi. Biaya pengeluaran yang terlalu tinggi berdampak pada harga jual cabai rawit. Hal ini menyebabkan rendahnya keuntungan petani karena berkurangnya daya beli masyarakat.

Pemberian pupuk anorganik berlebih secara terus menerus berdampak pada kerusakan fisik, kimia, dan biologi tanah. Penggunaan pupuk anorganik berlebih akan mengganggu keseimbangan jumlah zat hara dalam tanah yang berakibat pada metabolisme tumbuhan. Tumbuhan akan mengalami berbagai macam penyakit akibat dari kelebihan maupun kekurangan zat hara tertentu. Dampak lain penggunaan pupuk anorganik berlebih adalah berkurangnya populasi mikroorganisme tanah yang menguntungkan. Akibatnya, tanah menjadi kurang subur karena berkurangnya mikroorganisme pengurai.

Berbagai permasalahan lingkungan akibat penggunaan pupuk anorganik berlebih serta mahalnya pupuk anorganik menyebabkan petani beralih menggunakan pupuk organik. Pupuk organik dihasilkan dari sisa organisme maupun limbah produksi pabrik. Salah satu limbah produksi pabrik yang dapat dimanfaatkan adalah limbah cair pengolahan tahu.
Limbah cair pengolahan tahu yang dibuang secara langsung berdampak pada lingkungan. Limbah cair yang dihasilkan mengandung padatan tersuspensi maupun terlarut, akan mengalami perubahan fisika, kimia, dan biologi. Salah satu contoh perubahannya adalah meningkatnya nilai COD (Chemical Oxygen Demand). Nilai COD merupakan ukuran bagi pencemaran air oleh bahan-bahan organik yang secara alamiah dapat dioksidasikan melalui proses biologis, dan mengakibatkan berkurangnya oksigen terlarut dalam air terkandung dalam limbah cair. Berkurangnya oksigen terlarut dalam air dapat mengganggu aktivitas hewan maupun tumbuhan di sekitar.

Suatu solusi dibutuhkan untuk mengurangi dampak dari berbagai permasalahan yang disebabkan dari penggunaan pupuk anorganik dan pembuangan limbah cair tahu tanpa pengolahan. Limbah cair dari pengolahan tahu dapat diolah menjadi pupuk organik. Pupuk limbah cair tahu dapat digunakan sebagai alternatif pengurangan penggunaan pupuk anorganik.

\section{Metode}

Penelitian dilakukan menggunakan pendekatan kuantitatif dengan metode eksperimen. Penelitian dilaksanakan di Desa Cendono, Kecamatan Dawe, Kabupaten Kudus. Penelitian dilakukan selama 2 bulan yaitu mulai bulan Agustus sampai Oktober 2015.

Alat yang digunakan dalam penelitian yaitu ember plastik, botol plastik, sekop/cangkul, label, penggaris, benang, alat tulis, 1 buah tray/nampan, 5 buah sprayer berukuran $100 \mathrm{ml}, 1$ buah sprayer berukuran 1 liter, polibag berdiameter $20 \mathrm{~cm} \mathrm{x}$ $20 \mathrm{~cm}$ sebanyak 20 buah, Soil tester, Lux meter, kamera ponsel dan kamera digital. Sedangkan bahan yang dibutuhkan antara lain, $1000 \mathrm{ml}$ air limbah tahu, $500 \mathrm{ml}$ air kelapa, dan $30 \mathrm{ml}$ EM4.

Rancangan percobaan yang digunakan adalah Rancangan Acak Lengkap (RAL) dengan 5 
perlakuan dan 4 kali pengulangan. Perlakuan yang akan digunakan sebanyak antara lain :

$\mathrm{T} 1$ = konsentrasi pupuk limbah cair tahu $0 \%$ (perlakuan kontrol)

$\mathrm{T} 2$ = konsentrasi pupuk limbah cair tahu 5\%

T3 = konsentrasi pupuk limbah cair tahu 10\%

T4 = konsentrasi pupuk limbah cair tahu 15\%

T5 = konsentrasi pupuk limbah cair tahu 20\%
Prosedur pelaksanaan penelitian antara lain

1. Pembuatan pupuk organik cair dari limbah

Pertama, memasukkan air limbah tahu pada ember plastik dan menambahkan air kelapa serta EM4. Selanjutnya, ember plastik ditutup rapat dan disimpan selama 10 hari. Pupuk yang telah jadi berwarna kuning kecoklatan. Selanjutnya, pupuk disimpan dalam botol plastik.

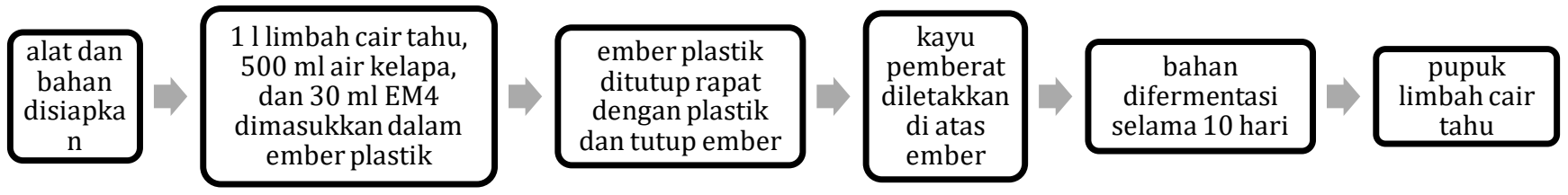

Gambar 1. Bagan alir pembuatan pupuk dari limbah cair tahu

2. Pengujian kadar nitrogen total, fosfor dan kalium pada pupuk limbah cair tahu

Pengujian dilakukan di Laboratorium Balai

Pengkajian Teknologi Pertanian Jawa Tengah. Pengujian total nitrogen menggunakan metode kjeldahl dan kadar fosfor dan kalium menggunakan metode spektrofotometri.

3. Pengukuran parameter lingkungan

Parameter lingkungan yang diukur dalam penelitian ini antara lain :

a. Intensitas cahaya, diukur dengan menggunakan Lux meter.

b. pH tanah, diukur dengan menggunakan Soil tester.

4. Persiapan benih

Biji tanaman cabai yang digunakan telah teruji kualitasnya yang didapatkan dari toko pertanian. Kriteria biji yang digunakan adalah biji yang bentuknya sempurna dan tidak cacat.

1. Persemaian

Media tumbuh dari campuran tanah dan arang sekam dengan perbandingan 1:1 lalu dimasukkan ke dalam tray. Biji cabai yang telah dipilih, ditanam pada media dan diusahakan agar biji tidak menumpuk dengan menggunakan semai baris yaitu ditaburkan pada baris-baris persemaian yang telah diolah, lalu ditutup dengan tanah tipis. Persemaian disimpan pada suhu kamar dengan menjaga kelembaban. Penyiraman air pada pagi dan sore hari. Setelah 4-7 hari dalam persemaian, tumbuh benih yang mengeluarkan radikula atau calon akar siap ditanam.

\section{Penanaman}

Bibit cabai umur 10-14 hari (biasanya telah tumbuh sepasang daun) sudah dapat dipindahkan ke polibag penanaman. Bibit cabai dipilih yang baik yaitu pertumbuhannya segar, warna daun hijau, tidak cacat atau terkena hama penyakit. Tempat penanaman bibit cabai rawit berupa polibag. Media tanam berupa campuran tanah dan arang sekam dengan perbandingan 1:1 dimasukkan ke dalam polibag.

Tanah di sekitar akar tanaman ditekan-tekan agar sedikit padat dan bibit berdiri tegak. Bibit ditanam tepat di bagian tengah. Bibit diletakkan di tempat yang tersinari matahari dan disirami secukupnya untuk menjaga kelembabannya.

3. Penyiraman

Penyiraman dilakukan secukupnya untuk menjaga kelembaban. Penyiraman dilakukan setiap hari pada pagi hari dan sore hari. Jika tanah terlalu kering penyiraman dapat dilakukan kembali. 


\section{Pemupukan}

Pemupukan dilakukan pada tanaman yang diberi perlakuan pupuk. Tanaman yang menjadi kontrol tidak diberi pupuk. Pupuk yang digunakan adalah pupuk dari limbah cair tahu. Pupuk diencerkan dengan air sebelum diaplikasikan. Pengenceran pupuk dibagi menjadi 4, yaitu :

a. Pupuk konsentrasi pupuk 5\%.

$50 \mathrm{ml}$ pupuk limbah tahu diencerkan dengan air sumur hingga mencapai volume $1000 \mathrm{ml} \mathrm{(1}$ liter). Kemudian dihomogenkan dan dimasukkan ke dalam botol plastik.

b. Pupuk konsentrasi pupuk $10 \%$.

$100 \mathrm{ml}$ pupuk limbah cair tahu diencerkan dengan air sumur hingga mencapai volume $1000 \mathrm{ml}$ (1 liter). Kemudian dihomogenkan dan dimasukkan ke dalam botol plastik.

c. Pupuk konsentrasi pupuk $15 \%$.

$150 \mathrm{ml}$ pupuk limbah tahu diencerkan dengan air sumur hingga mencapai volume $1000 \mathrm{ml}$ (1 liter). Kemudian dihomogenkan dan dimasukkan ke dalam botol plastik.

d. Pupuk konsentrasi pupuk 20\%.

$200 \mathrm{ml}$ pupuk limbah tahu diencerkan dengan air sumur hingga mencapai volume $1000 \mathrm{ml}$ (1 liter). Kemudian dihomogenkan dan dimasukkan ke dalam botol plastik.

Pemberian pupuk dengan cara disemprot pada tanah menggunakan sprayer. Pemberian pupuk dilakukan 1 minggu setelah semaian cabai dipindah ke polibag sebanyak $100 \mathrm{ml}$. Pemberian pupuk selanjutnya setiap 1 minggu sekali selama 4 minggu. Pembatasan pemberian pupuk sampai 4 minggu dikarenakan penelitian dilakukan hanya pada fase pertumbuhan vegetatif tanaman.

1. Pengukuran parameter dalam penelitian

Pengamatan dilakukan terhadap jumlah daun, diameter batang dan tinggi tanaman.

1) Jumlah helai daun dihitung saat pengamatan setiap satu minggu sekali.

2) Diameter batang dihitung dari keliling batang. Sebelumnya, keliling batang diukur dengan menggunakan benang. Keliling batang yang telah diukur digunakan untuk menghitung diameter dengan menggunakan rumus diameter lingkaran. Pengukuran diameter batang dilakukan setiap satu minggu sekali.

3) Pengukuran tinggi tanaman dilakukan dengan menggunakan penggaris. Pengukuran dimulai dari pangkal batang yang sudah ditandai sebelumnya ( $\pm 1 \mathrm{~cm}$ di atas media) hingga titik tumbuh pucuk apikal. Pengamatan dilakukan setiap satu minggu sekali dari awal penanaman hingga minggu terakhir pengamatan.

Analisis data yang digunakan adalah uji asumsi ANOVA, One-way ANOVA, dan uji lanjutan Beda Nyata Terkecil (BNT).

\section{Hasil dan Pembahasan}

Pupuk limbah cair tahu dibuat dari limbah cair tahu, air kelapa dan EM4. Limbah cair tahu diubah menjadi pupuk melalui proses fermentasi dengan bantuan bioaktivator EM4. Fermentasi terjadi pada kondisi lingkungan anaerob. Selama proses fermentasi, mikroorganisme dalam EM4 memecah substrat menjadi senyawa yang lebih kecil.

Limbah cair tahu memiliki kandungan protein berasal dari kedelai yang merupakan bahan pembuatan tahu. Protein juga terdapat dalam air kelapa. Protein pada limbah tahu dan air kelapa diubah menjadi asam amino. Asam amino terdiri atas gugus amino dan asam karboksilat. Gugus amino memiliki unsur nitrogen dalam rumus molekulnya, yaitu $\mathrm{NH}_{2}$. Limbah cair tahu dan air kelapa juga memiliki kandungan karbohidrat. Karbohidrat diuraikan menjadi glukosa yang merupakan sumber energi bagi mikroorganisme sehingga dapat mempercepat proses fermentasi.

Pupuk limbah cair tahu memiliki kandungan unsur hara nitrogen, fosfor, dan kalium. Pemberian pupuk limbah cair tahu berpengaruh pada pertumbuhan tanaman cabai rawit. Pengaruh pupuk cair limbah tahu dapat dilihat dari hasil pengamatan terhadap tiga parameter pertumbuhan 
antara lain, diameter batang, tinggi tanaman dan jumlah helai daun.

\section{Diameter Batang}

Pemberian perlakuan pupuk menunjukkan jumlah rerata diameter batang yang lebih besar dibanding dengan perlakuan kontrol. Rerata diameter batang dengan perlakuan pupuk konsentrasi $20 \%, 15 \%, 10 \%$ dan 5\% sebesar
0,9314; 0,$9235 ; 0,9551$ dan 0,8597 . Sedangkan perlakuan kontrol hanya sebesar $0,7483 \mathrm{~cm}$. Hasil uji One-way ANOVA data diameter batang menunjukkan angka 0,001 lebih kecil dari 0,05 ( $\alpha=5 \%$ ). Sedangkan nilai $\mathrm{F}_{\text {hitung }}$ sebesar 8,257 lebih besar dari Ftabel yaitu 3,06. Hasil uji disajikan pada Tabel 1.

Tabel 1. Hasil Uji One-way ANOVA diameter batang dengan $\alpha=5 \%$

\begin{tabular}{|c|c|c|c|c|c|}
\hline & $\begin{array}{c}\text { Sum of } \\
\text { Squares }\end{array}$ & df & Mean Square & $\mathrm{F}$ & Sig. \\
\hline Between Groups & .009 & 4 & .002 & 8.257 & .001 \\
\hline Within Groups & .004 & 15 & .000 & & \\
\hline Total & .013 & 19 & & & \\
\hline
\end{tabular}

\section{Tinggi Tanaman}

Pemberian perlakuan pupuk menunjukkan jumlah rerata tinggi tanaman yang lebih besar dibanding dengan perlakuan kontrol. Tinggi tanaman dengan perlakuan pupuk konsentrasi 20\%, 15\%, 10\% dan $5 \%$ memiliki rerata 29,55; 29,35; 33,225 dan 28,625. Rerata tinggi tanaman perlakuan kontrol hanya sebesar 24,05cm. Hasil uji One-way ANOVA menunjukkan terdapat perbedaan tinggi tanaman setelah pemberian perlakuan. Nilai signifikansi data sampel menunjukkan angka 0,001 lebih kecil dari 0,05

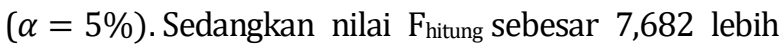
besar dari $\mathrm{F}_{\text {tabel }}$ yaitu 3,06. Hasil uji disajikan pada Tabel 2.

Tabel 2. Hasil Uji One-way ANOVA Tinggi Tanaman dengan $\alpha=5 \%$

\begin{tabular}{|c|c|c|c|c|c|}
\hline & $\begin{array}{c}\text { Sum of } \\
\text { Squares }\end{array}$ & $\mathrm{df}$ & Mean Square & $\mathrm{F}$ & Sig. \\
\hline Between Groups & 10.728 & 4 & 2.682 & 7.682 & .001 \\
\hline Within Groups & 5.237 & 15 & .349 & & \\
\hline Total & 15.964 & 19 & & & \\
\hline
\end{tabular}




\section{Jumlah Helai Daun}

Pemberian perlakuan pupuk menunjukkan rerata jumlah helai daun yang lebih besar dibanding dengan perlakuan kontrol. Rerata jumlah helai daun dengan perlakuan pupuk konsentrasi 20\%, 15\%, $10 \%$ dan 5\% dengan rerata 26,25; 26; 29 dan 24,75. Sedangkan perlakuan kontrol hanya sebesar 21,25.
Hasil uji One-way ANOVA menunjukkan terdapat perbedaan jumlah helai daun setelah pemberian perlakuan. Nilai signifikansi data sampel menunjukkan angka 0,001 lebih kecil dari 0,05 $(\alpha=$ 5\%). Sedangkan nilai Fhitung sebesar 9,455 lebih besar dari Ftabel yaitu 3,06. Hasil uji disajikan pada Tabel 3.

Tabel 3. Hasil Uji One-way ANOVA Jumlah Helai Daun dengan $\alpha=5 \%$

\begin{tabular}{|c|c|c|c|c|c|}
\hline & $\begin{array}{l}\text { Sum of } \\
\text { Squares }\end{array}$ & Df & Mean Square & $\mathrm{F}$ & Sig. \\
\hline Between Groups & 7.919 & 4 & 1.980 & 9.455 & .001 \\
\hline Within Groups & 3.141 & 15 & .209 & & \\
\hline Total & 11.059 & 19 & & & \\
\hline
\end{tabular}

Hasil uji One-way ANOVA menunjukkan pemberian perlakuan menunjukkan perbedaan pada diameter batang, tinggi tanaman dan jumlah helai daun. Selanjutnya dilakukan uji BNT (LSD) untuk menentukan perbandingan antara perlakuan pupuk dan perlakuan kontrol terhadap hasil rerata diameter batang, tinggi tanaman, dan jumlah helai daun tanaman cabai rawit. Hasil uji BNT diameter batang, tinggi tanaman, dan jumlah helai daun disajikan dalam Tabel 4,

Tabel 4. Hasil Uji BNT Diameter Batang, Tinggi, dan Jumlah Helai Daun Tanaman Cabai Rawit

\begin{tabular}{|c|l|l|l|}
\hline Perlakuan & \multicolumn{1}{|c|}{ Diameter Batang } & Tinggi Tanaman & \multicolumn{1}{|c|}{ Jumlah Helai Daun } \\
\hline T1 & $0,187075 \mathrm{a}$ & $6,0125 \mathrm{a}$ & $5,3125 \mathrm{a}$ \\
\hline T2 & $0,214925 \mathrm{~b}$ & $7,15625 \mathrm{~b}$ & $6,1875 \mathrm{~b}$ \\
\hline T3 & $0,248775 \mathrm{bc}$ & $7,3375 \mathrm{~b}$ & $7.25 \mathrm{~b}$ \\
\hline T4 & $0,230875 \mathrm{bc}$ & $7,3875 \mathrm{~b}$ & $6.5 \mathrm{bc}$ \\
\hline T5 & $0,23285 \mathrm{c}$ & $8,30625 \mathrm{c}$ & $6.5625 \mathrm{c}$ \\
\hline
\end{tabular}

Keterangan : rerata yang diikuti huruf sama tidak memiliki perbedaan signifikan pada taraf signifikansi $5 \%(\alpha=5 \%)$.

Hasil uji BNT diameter batang menunjukkan bahwa perlakuan pupuk 5\%, 15\% dan 20\% tidak memiliki perbedaan yang signifikan. Perlakuan pupuk 10\%, $15 \%$ dan $20 \%$ tidak terdapat perbedaan signifikan di antara ketiganya. Perlakuan 5\%, 10\%, 15\%, dan 20\% memiliki perbedaan signifikan dengan perlakuan kontrol.
Pemberian pupuk limbah cair tahu memberikan pengaruh terhadap diameter batang. Diameter batang bertambah besar karena adanya pembelahan sel akibat aktivitas meristem lateral. Pembelahan sel pada meristem lateral dapat menambah ukuran diameter organ (Gardner, 1991). Pembelahan sel merupakan proses yang dikendalikan oleh inti sel. Unsur fosfor merupakan 
bagian dari inti sel. Fosfor adalah unsur yang terdapat pada nukleotida yang merupakan pembentuk asam nukleat. Nitrogen dan kalium juga berpengaruh dalam penambahan diameter batang. Nitrogen merupakan bagian dari protein dan protoplasma, enzim, katalis biologis yang mempercepat proses metabolisme. Sedangkan kalium berperan dalam pembentukan protein.

Hasil uji BNT tinggi tanaman menunjukkan perlakuan pupuk $10 \%, 15 \%$ dan $20 \%$ antara ketiganya tidak berbeda secara signifikan. Perlakuan pupuk 5\%, 10\%, 15\% dan 20\% berbeda signifikan dengan perlakuan kontrol. Pemberian perlakuan pupuk limbah cair tahu menunjukkan perbedaan tinggi tanaman. Penambahan tinggi tanaman terjadi di dalam meristem interkalar pada ruas batang. Aktivitas meristem apikal juga menyebabkan perbanyakan sel baru di ujung tanaman sehingga tanaman menjadi tinggi.

Unsur nitrogen, fosfor dan kalium berpengaruh dalam aktivitas meristem. Nitrogen berfungsi dalam percepatan pertumbuhan. Nitrogen merupakan pembentuk protein. Fosfor merupakan bagian inti sel yang mengendalikan semua aktivitas dalam sel termasuk pembelahan sel. Kalium dalam pupuk berfungsi sebagai pembentuk protein.

Hasil uji BNT jumlah helai daun menunjukkan perlakuan pupuk 5\%, 15\% dan 20\% tidak berbeda signifikan. Perlakuan pupuk 5\%, $10 \%$, 15\% dan $20 \%$ menunjukkan perbedaan signifikan dengan perlakuan kontrol. Pemberian perlakuan pupuk limbah cair tahu menunjukkan perbedaan terhadap jumlah helai daun tanaman cabai rawit. Pupuk limbah cair tahu memiliki kandungan nitrogen. Nitrogen merupakan unsur yang paling berpengaruh dalam pertumbuhan dan perkembangan daun.

Tanaman cabai rawit membutuhkan unsur hara terutama nitrogen, fosfor dan kalium. Nitrogen berfungsi untuk mempercepat pertumbuhan tanaman. Fosfor merupakan salah satu unsur pembentuk Adenosin Tri Phospat (ATP). Fosfor juga terdapat dalam DNA, membentuk nukleotida. Kalium berfungsi dalam berbagai proses metabolisme.

Pupuk limbah cair tahu memiliki kadar Ntotal, $\mathrm{P}_{2} \mathrm{O}_{5}$, dan $\mathrm{K}_{2} \mathrm{O}$ pada pupuk limbah cair tahu sebesar 0,05\%, 0,07\%, dan 0,07\%. Jumlah tersebut menunjukkan kadar pupuk limbah cair tahu lebih rendah dibandingkan standar mutu. Kadar N-total, $\mathrm{P}_{2} \mathrm{O}_{5}$ dan $\mathrm{K}_{2} \mathrm{O}$ yang ditetapkan dalam Peraturan Menteri Pertanian No. 70/Permentan/SR.140/10/ 2011 yaitu masing-masing sebesar 3-6\%.

Rendahnya nitrogen, fosfor dan kalium pada pupuk limbah cair tahu dikarenakan bahan limbah tahu yang digunakan. Limbah cair tahu yang digunakan merupakan limbah yang paling akhir dari pengolahan tahu sehingga kandungan protein tidak terlalu banyak. Penelitian yang telah dilakukan oleh Yuliadi Asmoro, Suranto dan D. Sutoyo, kandungan nitrogen, dan $\mathrm{K}_{2} \mathrm{O}$ dalam limbah tahu padat (ampas tahu) sebesar 1,24\% dan 1,34\%. Hasil tersebut lebih besar dibandingkan limbah cair tahu yang hanya sebesar $0,27 \%$ nitrogen dan $0,29 \%$ $\mathrm{K}_{2} \mathrm{O}$. Kandungan $\mathrm{P}_{2} \mathrm{O}_{5}$ limbah padat sebesar 5,54 ppm lebih kecil dari 228,5 ppm pada limbah cair tahu.

Standar pupuk dalam Peraturan Menteri Pertanian No. 70/140/10/2011 ditetapkan untuk pupuk yang diproduksi dengan tujuan dipasarkan kepada masyarakat. Penggunaan pupuk cair yang telah memenuhi standar biasanya diencerkan terlebih dahulu sebelum diaplikasikan. Pengenceran bertujuan untuk menurunkan konsentrasi pupuk. Pupuk limbah cair tahu bisa digunakan untuk meningkatkan pertumbuhan tanaman cabai rawit karena dari hasil pengamatan menunjukkan pengaruh terhadap diameter batang, tinggi tanaman dan jumlah helai daun tanaman cabai rawit.

Hasil uji BNT diameter batang, tinggi tanaman dan jumlah helai daun menunjukkan 
antara perlakuan $10 \%$ dengan perlakuan kontrol memiliki selisih rerata terbesar dibandingkan selisih rerata perlakuan konsentrasi pupuk lain dengan perlakuan kontrol. Selisih rerata antara perlakuan $10 \%$ dan kontrol pada diameter batang yaitu 0,061700 . Selisih rerata perlakuan $10 \%$ dan kontrol pada tinggi tanaman sebesar 2,293750 sedangkan pada jumlah helai daun sebesar 1,93750. Hal ini menunjukkan bahwa perlakuan 10\% memiliki pengaruh yang paling besar terhadap pertumbuhan.

Pertumbuhan dipengaruhi oleh faktor salah satunya adalah penyerapan unsur hara. Penyerapan unsur hara dipengaruhi aerasi dalam tanah. Aerasi yang baik memungkinkan pertukaran udara di dalam tanah. Aerasi yang tidak baik membuat tanah kekurangan kadar oksigennya. Rendahnya kadar oksigen akan menghambat respirasi aerob oleh akar, sehingga energi yang didapat untuk penyerapan zat hara juga berkurang. Aerasi yang buruk ditandai dengan lambatnya air menyerap kedalam tanah karena kejenuhan air dalam tanah. Lambatnya air saat menyerap ke dalam tanah terlihat pada saat dilakukan penyiraman pada beberapa media tanam untuk perlakuan di atas $10 \%$.

Aerasi yang buruk akan meningkatkan kadar $\mathrm{CO}_{2}$ sehingga kekentalan protoplasma naik yang menyebabkan permeabilitas akar terhadap air berkurang. Hal tersebut menyebabkan tanaman menjadi layu. Layunya tanaman pada umumnya terlihat dari daun yang lemas dan batang menunduk. Pada tanaman cabai yang diberi perlakuan di atas 10\% menunjukkan gejala layu. Daun tanaman cabai terlihat lemas dan batangnya agak merunduk.

Faktor yang menyebabkan penyerapan unsur hara berkurang selain aerasi adalah sifat unsur terutama nitrogen yang mudah tercuci dan menguap jika dalam bentuk ion. Unsur nitrogen diserap oleh tanaman ditentukan ion NO3- dan
$\mathrm{NH}^{+}$yang pasokannya dipengaruhi oleh $\mathrm{N}$-total tanah. Jumlah $\mathrm{N}$-total meningkat bersamaan dengan meningkatnya pemberian pupuk yang memiliki kadar nitrogen. Namun, peningkatan pemberian pupuk dengan kadar nitrogen tidak menyebabkan pasokan $\mathrm{NO}^{-}$dan $\mathrm{NH}^{+}$tersedia bagi tanaman. Nitrogen akan menguap dan mengurangi kadar nitrogen yang bisa diserap tanaman. Nitrogen merupakan salah satu unsur yang dibutuhkan tanaman dalam proses pertumbuhan. Nitrogen merupakan bagian dari enzim yang merupakan biokatalisator pada setiap reaksi metabolisme. Pasokan unsur nitrogen dalam bentuk ion NO3- dan $\mathrm{NH} 4^{+}$akan mempengaruhi pertumbuhan tanaman. Kekurangan nitrogen menyebabkan pertumbuhan terhambat.

\section{Kesimpulan}

Pemberian perlakuan pupuk dari limbah cair tahu menunjukkan pengaruh terhadap pertumbuhan tanaman Cabai Rawit (Capsicum frutescens L.). Hal ini terlihat dari hasil uji One-way ANOVA menunjukkan $\mathrm{F}_{\text {hitung }}$ diameter batang, tinggi tanaman, dan jumlah helai daun lebih besar dibandingkan $\mathrm{F}_{\text {tabel }}$ pada $\alpha=5 \%$. Sedangkan dari hasil uji BNT menunjukkan adanya pengaruh pemberian perlakuan pupuk limbah cair tahu konsentrasi 5\%, 10\%, 15\% dan 20\% dibandingkan perlakuan kontrol. Perlakuan pupuk konsentrasi $10 \%$ menunjukkan pengaruh yang paling baik.

\section{Daftar Pustaka}

Amilia, Yuseffa. 2011. Penggunaan Pupuk Organik Cair untuk Mengurangi Dosis Penggunaan Pupuk Anorganik Pada Padi Sawah (Oryza sativa L.). Skripsi. IPB. Bogor.

Asmoro, Yuliadi dkk. 2008. Pemanfaatan Limbah Tahu untuk Peningkatan Hasil Tanaman Petsai (Brassica chinensis), Jurnal Bioteknologi, Vol. 5 No. 2.

Dwijoseputro, D. 1994. Dasar-dasar Mikrobiologi. Djambatan. Jakarta.

Fajriyah, Dhila Fadlilatul. Air Kelapa. http://ndukdhila.blogspot.co.id/2013/03/ai 
r-kelapa.html diakses pada tanggal 21 Oktober 2015 pukul 16:17 WIB.

Firmansyah, I. dan Sumarni, N. 2013. Pengaruh Dosis Pupuk N dan Varietas Terhadap pH Tanah,N-Total Tanah, Serapan N, dan Hasil Umbi Bawang Merah (Allium ascalonicum L.) pada Tanah Entisols-Brebes Jawa Tengah. J. Hort., 23(4).

Fithriyah, Nur Rahmah. Studi Pemanfaatan Limbah Cair Tahu untuk Pupuk Cair Tanam (Studi Kasus Pabrik Tahu Kenjeran). Paper. ITS. Surabaya.

Francis, John. K. Capsicum frutesces $L$. www.fs.fed.us/global/iitf/pdf/shrubs/Capsi cum\%20frutescens.pdf diakses pada tanggal 23 Maret 2015 pukul 09:18 WIB.

Gardner, Franklin P., dkk. 1991. Physiology of Crop Plants, terj. Herawati Susilo \& Subiyanto. UIPress. Jakarta.

Ginting, Rohani Cinta Badia dkk, 7 Mikroorganisme Pelarut Fosfat.

Hanafiah, Kemas Ali. 2011. Rancangan Percobaan (Teori dan Aplikasi) Edisi Ketiga. PT. Raja Grafindo Persada. Jakarta.

Handajani, Hani. 2006. Pemanfaatan Limbah Cair Tahu sebagai Pupuk Alternatif pada Kultur Mikroalga Spirullina sp.. Jurnal Protein, Vol. 13, No. 02.

Jumin, Hasan Basri. 1992. Ekologi Tanaman: Suatu Pendekatan Fisiologis. Rajawali. Jakarta..

Kaswinarni, Fibria. 2007. Kajian Teknis Pengolahan Limbah Padat dan Cair Industri Tahu (Studi Kasus Industri Tahu Tandang Semarang, Sederhana Kendal dan Gagak Sipat Boyolali. Tesis. Universitas Diponegoro. Semarang.

Lakitan, Benyamin. 1996. Fisiologi Pertumbuhan dan Perkembangan Tanaman. PT. Raja Grafindo Persada. Jakarta.

Makiyah, Mujiatul. 2013. Analisis Kadar N, P, dan K pada Pupuk Cair Limbah Tahu dengan Penambahan Tanaman Matahari Meksiko (Thitonia diversivolia). Skripsi. Unnes. Semarang.

Rahman, Syaiful. 2010. Meraup Untung Bertanam Cabai Rawit dengan Polibag. Lily Publisher. Yogyakarta.
Rao, N. S. Subba. 1994. Mikroorganisme Tanah dan Pertumbuhan, terj. Herawati Susilo. UI-Press. Jakarta.

Rosmarkam, Afandie dan Yuwono, Nasih Widya. 2002. Ilmu Kesuburan Tanah. Kanisius. Yogyakarta.

Rukiyati, Desy. 2013. Pembuatan EM4. http://desyrukiyati.blogspot.com/2013/06/ tugas-individu-pembuatan-em4.html diakses pada tanggal 20 Juni 2015 pukul 09:23 WIB.

Sutedjo, Mul Mulyani. 2002. Pupuk dan Cara Pemupukan. PT. Rineka Cipta. Jakarta.

Tim Badan Ketahanan Pangan dan Pelaksana Penyuluhan Malang, bkp3.malangkab.go.id/berita-25.html diakses pada tanggal 18 Februari 2015 pukul 09.30 WIB.

Tim BPS. Produksi Cabai Besar Tahun 2012 Naik 7,37 Persen dibandingkan Tahun Sebelumnya. Dalam

http://www.bps.go.id/webbeta/frontend/in dex.php/brs/168 diakses pada tanggal 05 Maret 2015 pukul 09:20 WIB.

Tjitrosoepomo, Gembong. 2002. Taksonomi Tumbuhan Obat-Obatan. Gadjah Mada University Press. Yogyakarta.

Utami, Arti Wahyu. 2013. Pengaruh Aerasi terhadap Pertumbuhan Tanaman. Makalah. Universitas Sebelas Maret. Surakarta.

Wahyudi. 2011. Meningkatkan Hasil Panen Sayuran dengan Teknologi EMP. AgroMedia Pustaka. Jakarta.

Wardhani, Shinta dkk. 2014. Pengaruh Aplikasi Pupuk Hayati terhadap Pertumbuhan dan Produktivitas Tanaman Cabai Rawit (Capsicum frutescens L.) Varietas Bhaskara di PT. Petrokimia Gresik. Jurnal Sains dan Seni Pomits, Vol. 2, No.1.

Waskito, Nugroho. Kondisi dan Permasalahan Pupuk Nasional di Indonesia. Dalam https://www.academia.edu/4697895/Kond isi_dan_Permasalahan_Pupuk_Nasional_di_In donesia diakses pada tanggal 05 Maret 2015 pukul 10:17 WIB.

Yulipriyanto, Hieronymus. 2010. Biologi Tanah dan Strategi Pengelolaannya. Graha Ilmu. Yogyakarta. 